\title{
Contagion in the LAC Financial Markets: The Impact of Stock Crises of 2008 and 2010
}

\author{
Rui Dias ${ }^{1}$, Paulo Alexandre ${ }^{1}$, Paula Heliodoro ${ }^{1}$ \\ ${ }^{1}$ Polytechnic Institute of Setúbal, School of Business and Administration, Portugal
}

\begin{abstract}
This research aims to evaluate financial contagion in the six main Latin Americ Countries (LAC) markets, as well as in the US, Greece and the EURO STOXX 50 indexes. Achieving this objective will allow us to answer the following questions: is there contagion among the emerging markets of Latin America? If so, what was the most critical moment of this phenomenon, the financial crisis of 2008 or 2010? If there is autocorrelation in the time series, will it be possible to detect serial volatility clusters? The results suggest the existence of financial contagion resulting from the financial crisis of 2008, with no significant contagion during the financial crisis of 2010. In the final phase, stock markets in Latin America have been infected by the subprime financial crisis. However, there was a readjustment in these regional markets during the European sovereign debt crisis of 2010, which could create conditions for implementing portfolio diversification strategies.
\end{abstract}

Keywords: financial contagion, financial crisis, LAC financial markets

\section{Introduction}

Until the 1980s, crises in emerging markets, particularly in Latin American countries, with their long history of heavy external debt, successive devaluations, bank crises and deep economic recessions were attributed to inconsistent domestic policies. Financial crises were considered as events that occurred in individual markets, without a systemic character and, therefore, little attention was paid to the possibility of the transmission of shocks between countries. 
The situation changed in the course of the 1990s as a series of serious financial crises unfolded: the crisis of the European Exchange Rate Mechanism in 1992, the Mexican crisis in 1994-95, the Southeast Asian crisis in 1997-98, the Russian crisis in 1998, the Brazilian crisis in 1999, the Dot-com crisis of 2000, and the Argentine crisis in 2001-2002. It is important to note that the negative consequences related to episodes of instability were not limited to the countries of origin but were transmitted rapidly to several markets with very diverse structures and dimensions throughout the world, representing what has been referred to in the literature as contagious effects.

The aim of this paper is to investigate the existence of financial contagion in the six main Latin American markets, as well as in the US, Greek and EURO STOXX 50 markets, during the period 2005-2012, especially in the crisis periods of 2008 and European sovereign debt in 2010. Forbes and Rigobon (2002) distinguish the effect of contagion from interdependence. According to these authors, interdependence occurs when the comovement does not increase significantly after a shock, while the contagion shows an increase in comovements in the face of any shock.

In order to achieve the proposed goal, this research tries to answer two questions, namely whether if: there was a phenomenon of contagion among the emerging markets of Latin America? If so, what would have been the most critical moment of such a phenomenon, the financial crisis of 2008 or 2010 ? If there is autocorrelation in the time series, will it be possible to detect temporal clusters of volatility?

The results suggest there was significant financial contagion during the 2008 financial crisis, with no evidence of contagion arising from the financial crisis of 2010. In the final phase, we found that financial markets in Latin America were infected by the subprime crisis. However, there was a readjustment in these regional markets during the financial crisis of 2010, creating conditions for the implementation of portfolio diversification strategies.

This research presents two contributions to the existing literature. The first contribution relates to the study of financial contagion in the six main Latin American markets, as well as in the US, Greek and EURO STOXX 50 markets, in the context of the financial crises of 2008 and 2010.

Some studies analysed the emerging markets of Latin America, namely, Chen, Firth and Meng Rui (2002) and Bejarano-Bejarano et al. (2015) and Dias, da Silva and Dionísio (2019) using a different approach from this research. Specifically, this paper presents different goals, derived in part from the sample period incorporating two subperiods of financial crisis and a subperiod of a rise in financial markets. The second contribution is related to the selection of these regional emerging markets, since, as far as we know, this is the first study to analyse the effects of the subprime and European sovereign debt crises on the financial markets of the LAC region. In addition, following the recent financial crisis of 2008 in international emerging markets, and those in Latin America, these markets have become an important investment destination. In this context and bearing in mind the large inflows of capital, it is important to understand the interdependencies between 
Latin American markets in order to provide relevant information for international investors about portfolio diversification strategies.

This paper is organized in 6 sections: Section 2 presents a review of the literature on contagion and interdependence in stock markets. Section 3 describes the methodology. Section 4 presents the data and results. Finally, Section 5 concludes.

\section{Literature Review}

The transmission of shocks in moments of crisis has been one of the main topics of research in the financial literature. There are many definitions of financial contagion adapted to the specific nature of each study. Given this, we will follow the definition of contagion according to Forbes and Rigobon (2002). According the authors, this is a significant increase in the links between markets after a shock in a country (or group of countries). In practical terms, it means that there is financial contagion when the correlation between the returns of two markets shows a significant increase after an unexpected event.

According to Dungey et al. (2006), the first empirical studies on contagion were carried out by Grubel and Fadner (1971). For example, Calvo and Reinhart (1996) studied the Mexican crisis of 1994/95 using correlation coefficients and concluded there was contagion in Latin America and Asia. Baig and Goldfajn (1999) also confirmed contagion in the markets of Malaysia, Indonesia, the Philippines and South Korea during the Asian crisis.

With some similarity, several empirical studies propose the presence of common creditors in the development of contagion episodes occurring throughout the 1980s and 1990s. Caramazza, Ricci and Salgado (2000) and Van Rijckeghem and Weder (2001) identified common factors in the presence of indirect effects of the financial channel through common creditors in the crises of Mexico, Southeast Asia and Russia. Hernández and Valdés (2001) found that the common creditor effect was the basis of the contagion episodes of Southeast Asia, Brazil and Russia when considering the propagation of shocks through the bond market. In the 1980s. Corsetti, Pericoli and Sbracia (2005) and Kaminsky, Lyons and Schmukler (2004) attribute the crises that have occurred in Latin America and Southeast Asia since the 1980s to the behaviour of the US, concerning loans to the regions. Bhimjee, Ramos and Dias (2016) looked at the banking sector before and after the subprime financial crisis from January 2002 to August 2010. The authors suggest that bank stock prices in emerging countries were less affected than the indices of the banking sectors of developed countries.

In more recent studies, several authors have analysed the 2008 financial crisis impacts. Luchtenberg and Vu (2015) studied the most relevant markets in North America, Europe and Asia, from January 1, 2003 to April 31, 2009. The authors concluded that the US market influences all the markets under study, except for China, Japan and Germany. The empirical evidence suggests a significant change in the behaviour of institutional 
investors in relation to risk at the beginning of the 2008 financial crisis. These results are in line with Kenourgios (2014), regarding the existence of increased risk aversion among institutional investors.

Cho, Hyde and Nguyen (2015) analysed 30,838 stocks corresponding to thirty-one markets in the period between 1973 and 2011. The results suggest that the subprime financial crisis affected markets globally, while the impacts of the Mexican and Asian crises were smoother and limited to the respective region of origin. In the same vein, Antonakakis, Breitenlechner and Scharler (2015) investigated the dynamic interdependencies between the real estate market, the stock market, political uncertainty and UK macroeconomic indicators from January 1997 to February 2015. The authors suggest that the subprime financial crisis promoted unprecedented shocks, more specifically in stock markets. The authors conclude that the contagion caused uncertainty in economic and monetary policy, with considerable effects on the real economy.

With some similarity, Karanasos, Yfanti and Karoglou (2016) analysed 8 stock markets, considering structure breaks, from 1988 to 2010. The authors argue that markets were abruptly infected by the financial crisis of 2008 when compared to the Asian financial crisis. Shahzad et al. (2017) analysed the Islamic financial markets and the US, UK and Japanese markets from July 15, 1996 to June 30, 2016. The results suggest that Islamic financial markets were infected, just as the developed markets under analysis. The authors argue that Islamic markets, not being immune to global contagion, hinder institutional investors when they want to diversify their investment portfolios, especially in financial crisis. BenSaïda (2017) analysed the US bond market and 10 European markets from January 1, 2000 to September 21, 2016. The results suggest financial contagion from the more developed markets to the peripheral Euro Zone markets, showing that the level of turbulence has remained high since the financial crisis of 2008 .

\section{Methodology and Data}

In order to answer the research questions, we will perform the descriptive statistics of returns, as well as tests on the stationarity of the time series. Next, we identify structure breaks in the data series using the Clemente, Montañés and Reyes (1998) test. The time persistence of returns will be evaluated through the Ljung-Box test, ARCH-LM (Engle, 1982) and BDS (Brock and de Lima, 1996). The importance of studying the level of autocorrelation in investigations related to contagion is due to the existence of clusters of volatility. According to Mandelbrot (1963) and Engle (1982) if volatility is high (low), in each period, it tends to continue to be volatile in the following period, since the new information that comes to the market is correlated in time.

To test for the existence of autocorrelation in time series, we use the Ljung-Box test (Ljung and Box, 1978). To determine the linearity of a series, the BDS test is often considered (Brock and de Lima, 1996). This test is an important tool to detect dependence in the time series, testing the null hypothesis of a series being i.i.d. (independently and identically 
distributed). According to Peters (2015) and Díaz, Grau-Carles and Mangas (2002), the test should be applied to filtered series of linear dependence, for example, the residuals of an ARMA process.

In order to understand whether linear correlations registered an increase with statistical significance, we apply the two-sample $t$ test, also called the $t$-test of heteroscedasticity, which results from Forbes and Rigobon (2002). This methodology adjusts the null hypothesis that the correlation in the crisis subperiod of 2010 is greater than or equal to the correlation in the two preceding subperiods, against the alternative hypothesis that the correlation is higher in the two preceding subperiods.

$$
\begin{aligned}
& \mathrm{H}_{0}=\mathrm{r}_{\mathrm{i}, \mathrm{j}}^{\mathrm{t}} \geq \mathrm{r}_{\mathrm{i}, \mathrm{j}}^{0} \\
& \mathrm{H}_{1}=r_{i, j}^{t}<r_{i, j}^{0}
\end{aligned}
$$

Where $r_{i, j}^{t}$ is the correlation coefficient between market $i$ and market $j$, in thet period.

In the previous scenarios, the subperiod of the sovereign debt crisis corresponds to the value " 1 ", while for the previous subperiod it corresponds to the value "0".

The use of this test considers Fisher's transformation (Fisher, 1930), which in turn is applied to the correlation coefficients, such that they present an approximate normal distribution, in asymptotic terms, with average $\mu_{t}$ and variance $\sigma_{t}^{2}$, defined as follows:

$$
\begin{aligned}
& \mu_{t}=\frac{1}{2} \ln \left(\frac{1+r_{i, j}^{t}}{1-r_{i, j}^{t}}\right) \\
& \sigma_{t}^{2}=\frac{1}{n_{t}-3}
\end{aligned}
$$

The test statistics are determined from

$$
U=\frac{\bar{\mu}_{1}-\bar{\mu}_{0}}{\left(\sigma_{0}^{2}+\sigma_{1}^{2}\right)^{\frac{1}{2}}}
$$

where $\mu_{t}$ and $\sigma_{t}^{2}$ are the average and the transformed sample variance. The test statistic follows normal distribution.

\section{Data}

In order to analyse contagion in Latin America, in the context of the financial crises of 2008 and 2010, we examined the returns of nine indexes, namely the six main markets in Latin America (Argentina, Brazil, Chile, Colombia, Peru and Mexico), as well as the US, Greece and the EURO index STOXX 50 in order to gauge the focus and origin of the crises 
under study. Daily closing prices of the various stock markets were obtained from the DataStream platform in US dollars. The daily returns, given by the difference of the logarithm of prices, cover the period from January 3, 2005 to April 30, 2012 (1910 observations). We divide the sample into three subperiods, one of pre-crisis, which we define as Calm Period, which corresponds to the subperiod from January 3, 2005 to July 31, 2007, and two subperiods, which we call Subprime Crisis Period (2008) and Sovereign Debt Crisis Period (2010). The Subprime Crisis Period comprises the subperiod from August 1, 2007 to December 7, 2009, while the Sovereign Debt Crisis Period corresponds to the subperiod from December 8, 2009 to April 30, 2012.

\section{Results}

In this section we present the data under study and the results obtained. In a first phase we analyse the stationarity tests and then the tests of the time persistence of returns, and the contagion tests.

In order to evaluate the stationarity of the series under study, we perform ADF and PP tests (Dickey and Fuller, 1981; Perron and Phillips, 1988) which have similar null hypotheses. We also used the KPSS test (Kwiatkowski et al., 1992) in order to evaluate the robustness of results.

The teste of Clemente, Montañés and Reyes's (1998) identified structural breaks in the three subperiods, making it difficult to identify periods of crisis and non-crisis (see Tables 1, 2 and 3). The structural breaks occurred in 2006 and 2007, i.e., in a period where subprime assets already present very significant risks.

Tab. 1: Clement Unit Root test for the 9 stock index returns, in the Calm Sub period

\begin{tabular}{|c|c|c|c|}
\hline Country & Index / Cod. & t-stat & Break Date \\
\hline Argentina & ARG & $-24.46(0)^{* * *}$ & $26 / 02 / 2007$ \\
\hline Brazil & BRA & $-23.86(0)^{* * *}$ & $19 / 05 / 2006$ \\
\hline Chile & CHI & $-24.82(0)^{* * *}$ & $26 / 02 / 2007$ \\
\hline Colombia & COL & $-22.51(0)^{* * *}$ & $14 / 06 / 2006$ \\
\hline Europe & EURO STOXX & $-27.34(0)^{* * *}$ & $13 / 03 / 2007$ \\
\hline Greece & GREECE & $-23.85(0)^{* * *}$ & $19 / 05 / 2006$ \\
\hline Mexico & MEX & $-22.57(0)^{* * *}$ & $26 / 02 / 2007$ \\
\hline Peru & PER & $-24.46(0)^{* * *}$ & $29 / 05 / 2007$ \\
\hline United States & USA & $-27.43(0)^{* * *}$ & $26 / 02 / 2007$ \\
\hline
\end{tabular}

Note: Lag Length (Automatic Length based on SIC). Break Selection: Minimize DickeyFuller t-statistic. The lateral values in parentheses refer to lags. ${ }^{* * *}$. **. *. represent significance at $1 \% .5 \%$ and $10 \%$. respectively.

Source: Authors.

In Table 2 it can be observed that the structure breaks are in line with the fall of Lehman Brothers Holdings Inc. On September 15, 2008, the company filed for bankruptcy, because of accumulated losses due to the large exposure of "subprime". These situations caused a lack of confidence, turbulence and, the pessimism experienced in the financial markets led to chaos in international markets. In addition, risk-aversion was so present in the 
behaviour of institutional investors, that it led to a mass flight from the stock markets and a reinvestment in the bond markets, the so-called "flight to quality..." assets.

Tab. 2: Clement Unit Root test for the 9 stock index returns, in the Subprime Crisis Sub period

\begin{tabular}{|c|c|c|c|}
\hline Country & Index / Cod. & t-stat & Break Date \\
\hline Argentina & ARG & $-22.05(0)^{* * *}$ & $06 / 03 / 2009$ \\
\hline Brazil & BRA & $-25.07(0)^{* * *}$ & $21 / 10 / 2008$ \\
\hline Chile & CHI & $-23.48(0)^{* * *}$ & $07 / 10 / 2008$ \\
\hline Colombia & COL & $-25.22(0)^{* * *}$ & $09 / 10 / 2008$ \\
\hline Europe & EURO STOXX & $-27.48(0)^{* * *}$ & $09 / 10 / 2008$ \\
\hline Greece & GREECE & $-23.37(0)^{* * *}$ & $23 / 10 / 2008$ \\
\hline Mexico & MEX & $-22.43(0)^{* * *}$ & $21 / 10 / 2008$ \\
\hline Peru & PER & $-22.43(0)^{* * *}$ & $09 / 10 / 2008$ \\
\hline United States & USA & $-28.81(0)^{* * *}$ & $14 / 10 / 2008$ \\
\hline
\end{tabular}

Note: Lag Length (Automatic Length based on SIC). Break Selection: Minimize DickeyFuller t-statistic. The lateral values in parentheses refer to lags. ***.**.*. represent significance at $1 \% .5 \%$ and $10 \%$. respectively.

Source: Authors.

From the very end of 2009, the fear of a public debt crisis developed among investors as a result of the increase in government and private debt levels in some European countries. The causes of the crisis have been different from country to country. In some countries, private debt originated from the real estate speculation bubble were transferred to public debt as a result of bailouts by the banking system and government responses to the economic slowdown in the post-bubble period. This situation put a lot of pressure on the financial markets causing significant structural breaks (see Table 3).

Tab. 3: Clement Unit Root test for the 9 stock index returns, in the Sovereign Debt Crisis Sub Period

\begin{tabular}{|c|c|c|c|}
\hline Country & Index / Cod. & t-stat & Break Date \\
\hline Argentina & ARG & $-23.25(0)^{* * *}$ & $17 / 04 / 2012$ \\
\hline Brazil & BRA & $-23.08(0)^{* * *}$ & $05 / 08 / 2011$ \\
\hline Chile & CHI & $-21.72(0)^{* * *}$ & $21 / 09 / 2011$ \\
\hline Colombia & COL & $-23.20(0)^{* * *}$ & $11 / 11 / 2010$ \\
\hline Europe & EURO STOXX & $-24.01(0)^{* * *}$ & $02 / 09 / 2011$ \\
\hline Greece & GREECE & $-24.66(0)^{* * *}$ & $26 / 08 / 2011$ \\
\hline Mexico & MEX & $-23.36(0)^{* * *}$ & $21 / 09 / 2011$ \\
\hline Peru & PER & $-22.63(0)^{* * *}$ & $03 / 06 / 2011$ \\
\hline United States & USA & $-27.69(0)^{* * *}$ & $05 / 08 / 2011$ \\
\hline
\end{tabular}

Note: Lag Length (Automatic Length based on SIC). Break Selection: Minimize DickeyFuller t-statistic. The lateral values in parentheses refer to lags. ${ }^{* * *}$. **. *. represent significance at $1 \% .5 \%$ and $10 \%$. respectively.

Source: Authors.

\section{Time persistence}

In order to analyse the presence of conditioned heteroscedasticity in the return series, we use the Lagrange Multiplier test (ARCH-LM test). 
The ARCH-LM test is applied to the residuals of the first-order autoregressive processes and the null hypothesis of homoscedasticity is rejected for all series. This means that residuals of the autoregressive processes of the return's series show conditional heteroscedasticity, corroborating this characteristic frequently present in financial assets. In addition, the results of the Ljung-Box tests, applied to the square of returns, for lags 4 and 12, confirm the results of the ARCH-LM test, showing the presence of ARCH effects in the time series under study (see Tables 4 and 5).

Tab. 4: Results of the Ljung-Box tests of index returns in the whole period

\begin{tabular}{|l|c|c|c|c|c|c|c|c|c|}
\hline & ARG & BRA & CHI & COL & EUA & EURO & GRE & MEX & PER \\
\hline LB (4) & $20,93^{*}$ & $10,37^{* *}$ & $39,71^{* *}$ & $35,29^{* *}$ & $27,17^{* *}$ & $24,17^{* *}$ & $13,44^{*}$ & $34,64^{* *}$ & $54,14^{*}$ \\
\hline LB (12) & $68,21^{*}$ & $33,89^{* *}$ & $73,60^{* *}$ & $55,93^{* *}$ & $44,39^{* *}$ & $35,91^{* *}$ & $27,23^{*}$ & $49,40^{* *}$ & $70,73^{*}$ \\
\hline LB $^{2}(4)$ & $56,48^{*}$ & $583,33^{*}$ & $429,36^{*}$ & $893,79^{*}$ & $608,04^{*}$ & $445,43^{*}$ & 260,08 & $495,43^{*}$ & 455,03 \\
\hline LB $^{2}(12)$ & 144,27 & 2256,1 & 1235,1 & 1265,6 & 2106,7 & 1056,3 & 708,64 & 1594,9 & 579,30 \\
\hline Observat & 1.910 & 1.910 & 1.910 & 1.910 & 1.910 & 1.910 & 1.910 & 1.910 & 1.910 \\
\hline
\end{tabular}

Note: Asterisks ***, ${ }^{* *}, *$, represent significance at $1 \%, 5 \%$ and $10 \%$, respectively.

Source: Authors.

Tab. 5: ARCH-LM test of the residuals of the autoregressive process for all return series in the whole period

\begin{tabular}{|l|c|c|c|c|c|c|c|c|c|}
\hline & ARG & BRA & CHI & COL & EUA & & GRE & MEX & PER \\
\hline ARC & $18,59^{*}$ & $60,32^{*}$ & $112,45^{*}$ & $207,88^{*}$ & $141,66^{*}$ & $113,29^{*}$ & $26,11^{*}$ & $108,64^{*}$ & $231,99^{*}$ \\
H-LM & $* *$ & $* *$ & $* *$ & $* *$ & $* *$ & $* *$ & $* *$ & $* *$ & $* *$ \\
\hline
\end{tabular}

Note: The LM test was applied to the residuals of a first-order autoregressive process (ARMA estimation) of each time series. The asterisks $* * *, * *, *$, represent significance at $1 \%, 5 \%$ and $10 \%$, respectively.

Source: Authors.

The residuals filtered from an ARMA model show the presence of nonlinear serial dependence, given rejection of the null hypothesis (see Table 6). According to Taylor, (1986), the significant presence of higher autocorrelation between the square returns than between the original return values also indicates the presence of non-linearity. Rejection of the null hypothesis of the BDS test can be explained, among other factors, by the existence of autocorrelation or by the existence of heteroscedasticity in the series of stock indexes and a possible sign of nonlinear serial dependence. These results are in line with studies by Appiah-Kusi and Menyah (2003) and Lim and Hinich (2005). 
Tab. 6: BDS test for filtered return series for the whole period

\begin{tabular}{|l|c|c|c|c|c|c|c|c|}
\hline & ARG & BRA & CHI & COL & EURO & MEX & PER & EUA \\
\hline $\mathrm{m}=2$ & $7,32^{* * *}$ & $7,98^{* * *}$ & $8,18^{* * *}$ & $11,13^{* * *}$ & $7,65^{* * *}$ & $10,39^{* * *}$ & $11,11^{* * *}$ & $7,75^{* * *}$ \\
\hline $\mathrm{m}=3$ & $9,48^{* * *}$ & $10,10^{* * *}$ & $10,37^{* * *}$ & $13,05^{* * *}$ & $10,90^{* * *}$ & $13,19^{* * *}$ & $12,95^{* * *}$ & $11,41^{* * *}$ \\
\hline $\mathrm{m}=4$ & $10,62^{* * *}$ & $12,00^{* * *}$ & $12,41^{* * *}$ & $14,20^{* * *}$ & $12,82^{* * *}$ & $14,97^{* * *}$ & $14,44^{* * *}$ & $13,93^{* * *}$ \\
\hline $\mathrm{m}=5$ & $11,32^{* *}$ & $13,31^{* * *}$ & $13,58^{* * *}$ & $14,59^{* * *}$ & $14,80^{* * *}$ & $16,61^{* * *}$ & $15,97^{* * *}$ & $16,31^{* * *}$ \\
\hline $\mathrm{m}=6$ & $12,10^{* * *}$ & $14,37^{* * *}$ & $14,86^{* * *}$ & $15,29^{* * *}$ & $16,58^{* * *}$ & $18,20^{* * *}$ & $17,45^{* * *}$ & $18,61^{* * *}$ \\
\hline
\end{tabular}

Notes: $m$ concerns the size of the dive (embedding dimension). The method considered in the BDS test was the fraction of standard deviation pairs, to a value of 0.7 . The method of estimation of the first order autoregressive process was the ARMA. The asterisks ***,**, ${ }^{*}$, represent significance at $1 \%, 5 \%$ and $10 \%$, respectively.

Source: Authors.

\section{Contagion among stock markets}

In order to analyse the occurrence of financial contagion among the nine indexes under study, the non-conditional correlations were estimated, and the statistical significance was examined. To test whether the matrix of correlation coefficients is globally different from an identity matrix, we use the likelihood ratio test, suggested by Pindyck and Rotemberg (1990).

In order to evaluate the significance of the co-movements between the indices under study, we apply the heteroscedasticttest of Forbes and Rigobon (2002). If the correlation coefficients between two markets are significant and the null hypothesis is rejected, the contagion effect occurs. If the correlation coefficients are significant and the null hypothesis is not rejected, there is an interdependence relation.

The results of the $t$ test, the contagion effect between the Calm Period and the Subprime Crisis Period. The results suggest the existence of 44 pairs that reject the null hypothesis and point to the existence of contagion. The remaining pairs, more specifically 28 pairs with significant correlation coefficients, do not reject the null hypothesis, indicating the presence of interdependence.

The Brazilian and Mexican Stock Exchanges, as well as the EURO STOXX50 index are the markets with the greatest effect on their peers. However, and surprisingly, the US market did not significantly affect some of the more important stock markets in Latin America, namely the Brazilian and Mexican markets.

These results are in line with those obtained by (Tola and Wälti, 2015; Gómez-Puig and Sosvilla-Rivero, 2016; Ehrmann and Fratzscher, 2017; Ters and Urban, 2018; Bahaj, 2020), suggesting that the Subprime Crisis has led to significant contagion in international financial markets.

The $t$-test results for the contagion effect between the Subprime Crisis Period and the Sovereign Debt Crisis Period (SDC). The results suggest the existence of 3 pairs rejecting the null hypothesis and 69 pairs with significant correlation coefficients, but that do not reject the null hypothesis. The results point to the existence of interdependence between stock markets. In addition, there are signs that the Sovereign Debt Crisis was not reflected 
in the Latin American stock markets. Specifically, after the chaos in the international markets as a result of the Subprime Crisis, investors started to diversify their portfolios, creating market liquidity and reducing the shocks resulting from the financial crisis of 2010. In view of these results, the implementation of portfolio diversification strategies in the stock markets of the LAC Region, in the sub-period 2010-2012, may be considered by international investors to minimize risk.

\section{Conclusions}

In this research, we study financial contagion in the six major Latin American markets, US, Greece and index EURO STOXX 50, in the context of the Subprime Crisis and Sovereign Debt Crisis. The main goal is to understand the behaviour and type of relationships between markets at times of financial crisis.

The general conclusion to be drawn from this research is supported by the results obtained from the econometric models, that is, the markets of Brazil and Mexico have "infected" all their regional peers. However, the US market was expected to have more expression in these regional markets. In the concluding phase, we believe that in the postcrisis period of the subprime financial crisis, portfolio diversification in these stock markets will be feasible because the level of contagion has decreased significantly.

In terms of future research, we believe this study should be complemented with analysis of sectoral indexes, and the inclusion of macroeconomic variables helps to explain in a deeper way, the relations between markets. It is also important to develop new approaches on the subject with the purpose of helping to clarify what is contagion or interdependence.

\section{References}

1. ANTONAKAKIS, N., M. BREITENLECHNER, J. SCHARLER, 2015. Business cycle and financial cycle spillovers in the G7 countries. Quarterly Review of Economics and Finance. 58, 154-162. doi: 10.1016/j.qref.2015.03.002.

2. APPIAH-KUSI, J., K. MENYAH, 2003. Return predictability in African stock markets. Review of Financial Economics. 12(3), 247-270. doi: 10.1016/S10583300(02)00073-3.

3. BAHAJ, S., 2020. Sovereign spreads in the Euro area: Cross border transmission and macroeconomic implications. Journal of Monetary Economics. 110, 116-135. doi: 10.1016/j.jmoneco.2019.01.006.

4. BAIG, T., I. GOLDFAJN, 1999. Financial Market Contagion in the Asian Crisis. IMF Staff Papers. 46(2). 167-195. doi: 10.1016/j.asieco.2009.07.001.

5. BEJARANO-BEJARANO, L. V. et al., 2015. Financial Contagion in Latin America. Borradores De Economia. Available from: http://ideas.repec.org/p/col/000094/012820.html. 
6. BENSAÏDA, A., 2017. The contagion effect in European sovereign debt markets: A regime-switching vine copula approach. International Review of Financial Analysis. 58, 153-165. doi: 10.1016/j.irfa.2017.09.013.

7. BHIMJEE, D. C., S. B. RAMOS, J. G. DIAS, 2016. Banking industry performance in the wake of the global financial crisis. International Review of Financial Analysis. 48, 376-387. doi: 10.1016/j.irfa.2016.01.005.

8. BROCK, W. A., P. J. F. DE LIMA, 1996. 11 Nonlinear time series, complexity theory, and finance. Handbook of Statistics. 317-361. doi: 10.1016/S01697161(96)14013-X.

9. CALVO, S. G., C. M. REINHART, 1996. Capital Flows to Latin America: Is There Evidence of Contagion Effects? Policy Research Working Paper 1619. Available from: http://papers.ssrn.com/abstract $=636120$.

10. CARAMAZZA, F., L. A. RICCI, R. SALGADO, 2000. Trade and financial contagion in currency crises, Issues 2000-2055. IMF working paper. 0-46.

11. CHEN, G., M. FIRTH, O. Meng RUI, 2002. Stock market linkages: Evidence from Latin America. Journal of Banking \& Finance. 26(6), 1113-1141. doi: 10.1016/S03784266(01)00160-1.

12. CHO, S., S. HYDE, N. NGUYEN, 2015. Time-varying regional and global integration and contagion: Evidence from style portfolios. International Review of Financial Analysis. 42, 109-131. doi: 10.1016/j.irfa.2014.10.007.

13. CLEMENTE, J., A. MONTAÑÉS, M. REYES, 1998. Testing for a unit root in variables with a double change in the mean. Economics Letters. 59(2), 175-182. doi: 10.1016/S0165-1765(98)00052-4.

14. CORRADIN, S., A. MADDALONI, 2020. The importance of being special: Repo markets during the crisis. Journal of Financial Economics. doi: 10.1016/j.jfineco.2020.02.006.

15. CORSETTI, G., M. PERICOLI, M. SBRACIA, 2005. "Some contagion, some interdependence": More pitfalls in tests of financial contagion. Journal of International Money and Finance. 24(8), 1177-1199. doi: 10.1016/j.jimonfin.2005.08.012.

16. DIAS, R., J. V. DA SILVA, A. DIONÍSIO, 2019. Financial markets of the LAC region: Does the crisis influence the financial integration?. International Review of Financial Analysis. 63, 160-173. doi: 10.1016/j.irfa.2019.02.008.

17. DÍAZ, A. F., P. GRAU-CARLES, L. E.MANGAS, 2002. Nonlinearities in the exchange rates returns and volatility. Physica A: Statistical Mechanics and its Applications. 316(1-4), 469-482. doi: 10.1016/S0378-4371(02)01203-7.

18. DICKEY, D., W. FULLER, 1981. Likelihood ratio statistics for autoregressive time series with a unit root. Econometrica. 49(4), 1057-1072. doi: 10.2307/1912517.

19. DUNGEY, M. et al. , 2006. Contagion in international bond markets during the Russian and the LTCM crises. Journal of Financial Stability. 2(1), 1-27. doi: 10.1016/j.jfs.2005.01.001.

20. EHRMANN, M., M. FRATZSCHER, 2017. Euro area government bonds Fragmentation and contagion during the sovereign debt crisis. Journal of 
International Money and Finance. $\mathbf{7 0}(\mathrm{C}), \quad 26-44 . \quad$ doi: 10.1016/j.jimonfin.2016.08.005.

21. ENGLE, R. F.,1982. Autoregressive Conditional Heteroscedasticity with Estimates of the Variance of United Kingdom Inflation. Econometrica. 50(4), 987. doi: $10.2307 / 1912773$.

22. FISHER, R. A., 1930. Inverse Probability. Mathematical Proceedings of the Cambridge Philosophical Society. 26(4), 528-535. doi: 10.1017/S0305004100016297.

23. FORBES, K. J., R. RIGOBON, 2002. No Contagion, Only Interdependence: Measuring Stock Market Comovements. The Journal of Finance. 57(5), 2223-2261. doi: $10.2307 / 3094510$.

24. GÓMEZ-PUIG, M., S. SOSVILLA-RIVERO, 2016. Causes and hazards of the euro area sovereign debt crisis: Pure and fundamentals-based contagion. Economic Modelling. 56, 133-147. doi: 10.1016/j.econmod.2016.03.017.

25. GRUBEL, H. G., K. FADNER, 1971. The Interdependence Of International Equity Markets. Journal of Finance. 26(1), 89-94. Available from: http://search.ebscohost.com/login.aspx?direct=true \&db=bth\&AN=4655774\&sit $\mathrm{e}=$ ehost-live $\&$ scope $=$ site.

26. HERNÁNDEZ, L. F., R. O. VALDÉS, 2001. What drives contagion. International Review of Financial Analysis. 10(3), 203-218. doi: 10.1016/S10575219(01)00052-7.

27. KAMINSKY, G., R. K. LYONS, S. L. SCHMUKLER, 2004. Managers, investors, and crises: Mutual fund strategies in emerging markets. Journal of International Economics. 64(1), 113-134. doi: 10.1016/S0022-1996(03)00075-8.

28. KARANASOS, M., S. YFANTI, M. KAROGLOU, 2016. Multivariate FIAPARCH modelling of financial markets with dynamic correlations in times of crisis. International Review of Financial Analysis. 45, 332-349. doi: 10.1016/j.irfa.2014.09.002.

29. KENOURGIOS, D., 2014. On financial contagion and implied market volatility. International Review of Financial Analysis. 34, 21-30. doi: 10.1016/j.irfa.2014.05.001.

30. KWIATKOWSKI, D. et al.,1992. Testing the null hypothesis of stationary against the alternative of a unit root. Journal of econometrics. 54(1), 159-178. doi: http://dx.doi.org/10.1016/0304-4076(92)90104-Y.

31. LIM, K. P., M. J. HINICH, 2005. Cross-temporal universality of non-linear dependencies in Asian stock markets. Economics Bulletin. 7(1).

32. LJUNG, G. M., G. E. BOX, 1978. On a measure of lack of fit in time series models. Biometrika. 65(2), 297-303. doi: 10.1093/biomet/65.2.297.

33. LUCHTENBERG, K. F., Q. V. VU, 2015. The 2008 financial crisis: Stock market contagion and its determinants. Research in International Business and Finance. 33, 178-203. doi: 10.1016/j.ribaf.2014.09.007.

34. MANDELBROT, B., 1963. The Variation of Certain Speculative Prices. The Journal of Business. 36(4), 394-419. doi: 10.1007/978-1-4757-2763-0_14. 
35. PETERS, E. E., 2015. Fractal market analysis : applying chaos theory to investment and economics. Wiley finance editions. Available from: https://books.google.com.co/books?hl=es\&lr=\&id=_bkoySKyc_cC\&oi=fnd\&pg=P A3\&dq $=($ Fractal + Market + Analysis: + Applying + Chaos + Theory + to + Investment + an $\mathrm{d}+$ Economics\&ots=sNzltsZ0IO\&sig=cnQpI_4F5zlD5blbhNH9omRATmo\%5Cnhttp ://www.loc.gov/catdir/description/wiley037/93028.

36. PINDYCK, R. S., J. J. ROTEMBERG, 1990. The Excess Co-Movement of Commodigy Prices. The Economic Journal. 100(403), 1173-1189.

37. VAN RIJCKEGHEM, C., B. WEDER, 2001. Sources of contagion: Is it finance or trade?. Journal of International Economics. 54(2), 293-308. doi: 10.1016/S00221996(00)00095-7.

38. SHAHZAD, S. J. H. et al., 2017. Risk transmission between Islamic and conventional stock markets: A return and volatility spillover analysis. International Review of Financial Analysis. 52, 9-26. doi: 10.1016/j.irfa.2017.04.005.

39. TAYLOR, J. B., 1986. Chapter 34 New econometric approaches to stabilization policy in stochastic models of macroeconomic fluctuations. Handbook of Econometrics. doi: 10.1016/S1573-4412(86)03014-3.

40. TERS, K., J. URBAN, 2018. Intraday dynamics of credit risk contagion before and during the euro area sovereign debt crisis: Evidence from central Europe. International Review of Economics and Finance. 54, 123-142. doi: 10.1016/j.iref.2017.08.002.

41. TOLA, A., S. WÄLTI, 2015. Deciphering financial contagion in the euro area during the crisis. Quarterly Review of Economics and Finance. 55, 108-123. doi: 10.1016/j.qref.2014.09.009.

\section{Contact address of the authors:}

Rui Dias, Polytechnic Institute of Setúbal, School of Business and Administration, ESCE, Campus do Instituto Politécnico de Setúbal, Estefanilha, 2914-503 Setúbal, Portugal, email: rui.dias@esce.ips.pt

Paulo Alexandre, Polytechnic Institute of Setúbal, School of Business and Administration, ESCE, Campus do Instituto Politécnico de Setúbal, Estefanilha, 2914-503 Setúbal, Portugal, e-mail: paulo.alexandre@esce.ips.pt

Paula Heliodoro, Polytechnic Institute of Setúbal, School of Business and Administration, ESCE, Campus do Instituto Politécnico de Setúbal, Estefanilha, 2914-503 Setúbal, Portugal, e-mail: paula.heliodoro@esce.ips.pt 


\section{Appendices}

\section{Appendix A: - Results of contagion between the sub periods Calm / Subprime financial crisis}

\begin{tabular}{|c|c|}
\hline Countries & Results \\
\hline Argentina - Brazil & Inexistent \\
\hline Argentina - Chile & Inexistent \\
\hline Argentina - Colombia & Contagion $(1,91)^{* *}$ \\
\hline Argentina - EUA & Inexistent \\
\hline Argentina - Euro & Inexistent \\
\hline Argentina - Greece & Contagion $(1,69)^{*}$ \\
\hline Argentina - Mexico & Inexistent \\
\hline Argentina - Peru & $\operatorname{Contagion}(3,99)^{* * *}$ \\
\hline Brazil-Argentina & Contagion $(2,70)^{* *}$ \\
\hline Brazil - Chile & Contagion $(2,37)^{* *}$ \\
\hline Brazil - Colombia & Contagion $(3,45)^{* * *}$ \\
\hline Brazil - USA & Contagion $(2,29)^{* *}$ \\
\hline Brazil - Euro & Contagion $(2,39)^{* *}$ \\
\hline Brazil - Greece & $\operatorname{Contagion}(3,30)^{* * *}$ \\
\hline Brazil - Mexico & Contagion $(1,48)^{*}$ \\
\hline Brazil - Peru & $\operatorname{Contagion}(4,61)^{* * *}$ \\
\hline Chile - Argentina & Contagion $(2,27)^{* *}$ \\
\hline Chile - Brazil & Inexistent \\
\hline Chile - Colombia & $\operatorname{Contagion}(3,13)^{* * *}$ \\
\hline Chile - USA & $\operatorname{Contagion}(1,83)^{* *}$ \\
\hline Chile - Euro & Contagion $(1,92)^{* *}$ \\
\hline Chile - Greece & Contagion $(2,96)^{* * *}$ \\
\hline Chile - Mexico & Inexistent \\
\hline Chile - Peru & Contagion $(4,52)^{* *}$ \\
\hline Colombia - Argentina & Inexistent \\
\hline Colombia - Brazil & Inexistent \\
\hline Colombia - Chile & Inexistent \\
\hline Colombia - EUA & Inexistent \\
\hline Colombia - Euro & Inexistent \\
\hline Colombia - Greece & Contagion $(2,07)^{* *}$ \\
\hline Colombia - Mexico & Inexistent \\
\hline Colombia - Peru & Contagion $(4,07)^{* * *}$ \\
\hline USA - Argentina & Inexistent \\
\hline USA - Brazil & Inexistent \\
\hline USA - Chile & Inexistent \\
\hline USA - Colombia & $\operatorname{Contagion}(2,00)^{* *}$ \\
\hline USA - Euro & Inexistent \\
\hline USA - Greece & Contagion $(1,86)^{* *}$ \\
\hline USA - Mexico & Inexistent \\
\hline USA - Peru & Contagion $(3,26)^{* * *}$ \\
\hline
\end{tabular}

\begin{tabular}{|c|c|}
\hline Countries & Results \\
\hline Euro - Argentina & Contagion $(2,66)^{* *}$ \\
\hline Euro - Brazil & $\operatorname{Contagion}(1,46)^{*}$ \\
\hline Euro - Chile & $\operatorname{Contagion}(2,31)^{* *}$ \\
\hline Euro - Colombia & $\operatorname{Contagion}(3,48)^{* * *}$ \\
\hline Euro - USA & $\operatorname{Contagion}(2,22)^{* *}$ \\
\hline Euro - Greece & $\operatorname{Contagion}(3,32)^{* * *}$ \\
\hline Euro - Mexico & $\operatorname{Contagion}(1,35)^{*}$ \\
\hline Euro - Peru & Contagion $(4,77)^{* * *}$ \\
\hline Greece - Argentina & Contagion $(1,45)^{*}$ \\
\hline Greece - Brazil & Inexistent \\
\hline Greece - Chile & Inexistent \\
\hline Greece - Colombia & $\operatorname{Contagion}(2,35)^{* *}$ \\
\hline Greece - EUA & Inexistent \\
\hline Greece - Euro & Inexistent \\
\hline Greece - Mexico & Inexistent \\
\hline Greece - Peru & $\operatorname{Contagion}(3,90)^{* * *}$ \\
\hline México - Argentina & Contagion $(2,51)^{* *}$ \\
\hline México - Brazil & $\operatorname{Contagion}(1,44)^{*}$ \\
\hline México - Chile & $\operatorname{Contagion}(2,19)^{* *}$ \\
\hline México - Colombia & $\operatorname{Contagion}(3,22)^{* * *}$ \\
\hline México - EUA & $\operatorname{Contagion}(2,13)^{* *}$ \\
\hline México - Euro & $\operatorname{Contagion}(2,20)^{* *}$ \\
\hline México - Greece & $\operatorname{Contagion}(3,08)^{* * *}$ \\
\hline México - Peru & Contagion $(4,32)^{* * *}$ \\
\hline Peru - Argentina & Contagion $(1,49)^{*}$ \\
\hline Peru - Brazil & Inexistent \\
\hline Peru - Chile & Inexistent \\
\hline Peru - Colombia & Contagion $(2,51)^{* *}$ \\
\hline Peru - USA & Inexistent \\
\hline Peru - Euro & Inexistent \\
\hline Peru - Greece & $\operatorname{Contagion}(2,30)^{* *}$ \\
\hline Peru - Mexico & Inexistent \\
\hline
\end{tabular}

Source: Own elaboration.

Note: Unicaudal significance to the right tail, 2.7638 (1\%), 1.8125 (5\%) and 1.3722 (10\%). Asterisks $* * *, * *, *$ indicate significant results at $1 \%, 5 \%$ and $10 \%$ respectively. 